\title{
A new duo for mineral exploration: apatite and zircon in granitoids from $\mathrm{Mt}$ Isa, Australia

\author{
MICHELLE MOXEY AND ELENA BELOUSOVA
}

Macquarie University

Presenting Author: m.moxey119@gmail.com

The use of indicator minerals, such as apatite and zircon, is a known method in mineral exploration for assessing the prosperity of a host rock [e.g. 1,2]. This includes research by Belousova et al. [3] regarding the trace element signatures of apatites in granitoids from the Mt Isa Inlier in northwestern Queensland, Australia; a region famed for its $\mathrm{Pb}-\mathrm{Zn}-\mathrm{Ag}, \mathrm{Cu}$, and $\mathrm{Cu}-\mathrm{Au}$ deposits. Rare-earth element patterns in these apatites are indicative of mineralisation in the granitoid host rocks, linked to the higher oxidation and fractionation of the parent magma.

However, the study by Belousova et al. [3] is limited in only assessing the trace-element patterns in apatite. Extending on this work, this study investigates zircons and apatites from these same Mt Isa samples [3]: the Squirrel Hills Granite, Wimberu Granite, Kalkadoon Granodiorite, and Malakoff Granite, to determine if similar distinguishing trace element patterns for the mineralisation-related and mineralisation-absent groups can be seen in the zircons. A benefit of combining both zircon and apatite for analysis is that the lower closure temperature of apatite $\left(375-600^{\circ} \mathrm{C}\right)$ may provide time-temperature constraints on retrograde or low-temperature prograde processes related to mineralisation of the host rocks [4,5].

Trace-element signatures, U-Pb, $\mathrm{Sr}$, and $\mathrm{Hf}$ isotopes are collected using laser ablation, triple quadrupole, and multicollector ICP-MS to confirm host rock mineralisation affinity and to distinguish any differences in age and traceelement chemistry between the two mineral groups. Additionally, we apply the newly proposed zircon oxybarometer for calculating the oxidation state of a silicate melt [6]. Here we will present the results of our research, with the aim of demonstrating the applicability of trace-element and isotopic signatures of the zircon-apatite mineral pair for indicating mineralisation in granitoid rocks.

[1] Lu et al. (2016) in Richards (ed.) SEG Spec. Publ.19, 329347. [2] Zhong et al. (2018) Miner. Deposita, 53, 855-870. [3] Belousova et al. (2001) Aust. J. Earth Sci., 48, 603-619. [4] Cochrane et al. (2014) Geochim. Cosmochim. Acta, 127, 39-56. [5] Schoene and Bowring (2007) Geochim. Cosmochim. Acta, 71, 165-185. [6] Loucks et al. (2020) J. Petrol., 61, egaa034. 